\title{
RESIDENTS' PERSPECTIVES TOWARDS CONSERVATION IN GEORGE TOWN WORLD HERITAGE CITY: A POST-UNESCO LISTING SCENARIO
}

\author{
Yoke Mui LIM, Suet Leng KHOO, Kean Siang CH'NG \\ Universiti Sains Malaysia, Malaysia
}

\begin{abstract}
Being inscribed as a UNESCO World Heritage City since 2008, this scenario calls into question the voices, the participation and the aspirations of George Town residents themselves in the process of planning and conserving their city. As an extension of a similar project undertaken in 2006, prior to the UNESCO listing, the present study sought to explore and understand the residents' perceptions and preferences of George Town as a Heritage City after the UNESCO listing. Using the same set of samples (i.e. 400 inner city residents), the findings from this study revealed the change of residents preference as well as their appreciation towards the value of heritage and its economic potential. More respondents are supportive on the protection of heritage buildings and maintaining a heritage city. The older generations are the advocates of the heritage houses and they are more willing to pay higher prices to own a heritage house in the city.
\end{abstract}

Key Words: heritage awareness, urban conservation, resident perspectives, George Town.

\section{Introduction}

The aspiration of governments for a 'renaissance' of their cities is central to the existing urban policy. Urban policies and rhetoric around the world are shaped towards this renaissance, or more popularly known as urban regeneration, to attract investment and middle-class populations back to the inner city. Simply put, regeneration will mean reinvestment in a location after a period of disinvestment (Shaw and Porter 2009: 1-2).

This phenomenon is also rapidly unfolding in the city state of Penang, Malaysia. Penang or 'Pulau Pinang' is one of the thirteen states found in Malaysia comprising of two separate areas, namely, the Penang Island (approximately 285 sq. km) and Seberang Perai (approximately 760 sq. $\mathrm{km}$ ) which is on the mainland of Peninsular Malaysia. In terms of economic growth and development, arguably, Penang is considered one of the more developed states in Malaysia located on the north-western coast of Peninsular Malaysia. In the context of this paper however, the discussion revolves around Penang Island only, where the unequivocal process of gentrification and regeneration is rapidly happening.

In the island state of Penang, the investment pattern in its capital city George Town is unique and worth exploring, especially after the city's inscription into UNESCO's Heritage List in 2008. Recent data from Penang Institute reported that the capital city of George Town has a population of approximately 1,253,748 persons (MacDonald 2012). Founded in 1786, George Town started off as a port-city and it was a vibrant hub for commerce (Lim 2005: 16). Traders from near and far as well as migrant workers from China and India came to George Town and this influx of migrant workers back then marked the start of change for the city of George Town. Inevitably, these early settlers have physically and spatially transformed George Town from uninhibited, lush forest into highly urbanized physical settings that we see today. 
Undoubtedly, George Town's urban morphology is influenced by the intermeshing of values, culture and way of life between natives and these newcomers to the island that they now call home. Such early traces of pluralism and diversity of cultures and socio-economic activities are attributable to the eclecticism of cultures that modern George Town portrays today. Collectively, these tangible and intangible outstanding universal values are instrumental towards George Town's inscription into UNESCO's World Heritage List on 7 July 2008. The city is also home to a large stock of about 10,000 pre-war buildings. These historic buildings date back to between late eighteen century and early nineteenth century. In George Town's World Heritage Site alone, there are a total of 4,665 historic buildings of which 2,344 buildings are located in the core zone and 2,321 buildings in the buffer zone (SGP 2011). The different zones are shown in Figure 1. The size of the core heritage zone is 99.35 hectares while the buffer zone is 89.29 hectares.

However, the city later felt into decline with the abolishment of the Rent Control Act in 2000. Collectively, the repeal of the Rent Control Act together with rapid new development in the outskirts and suburban areas of Penang have witnessed a hollowing out process in the inner city

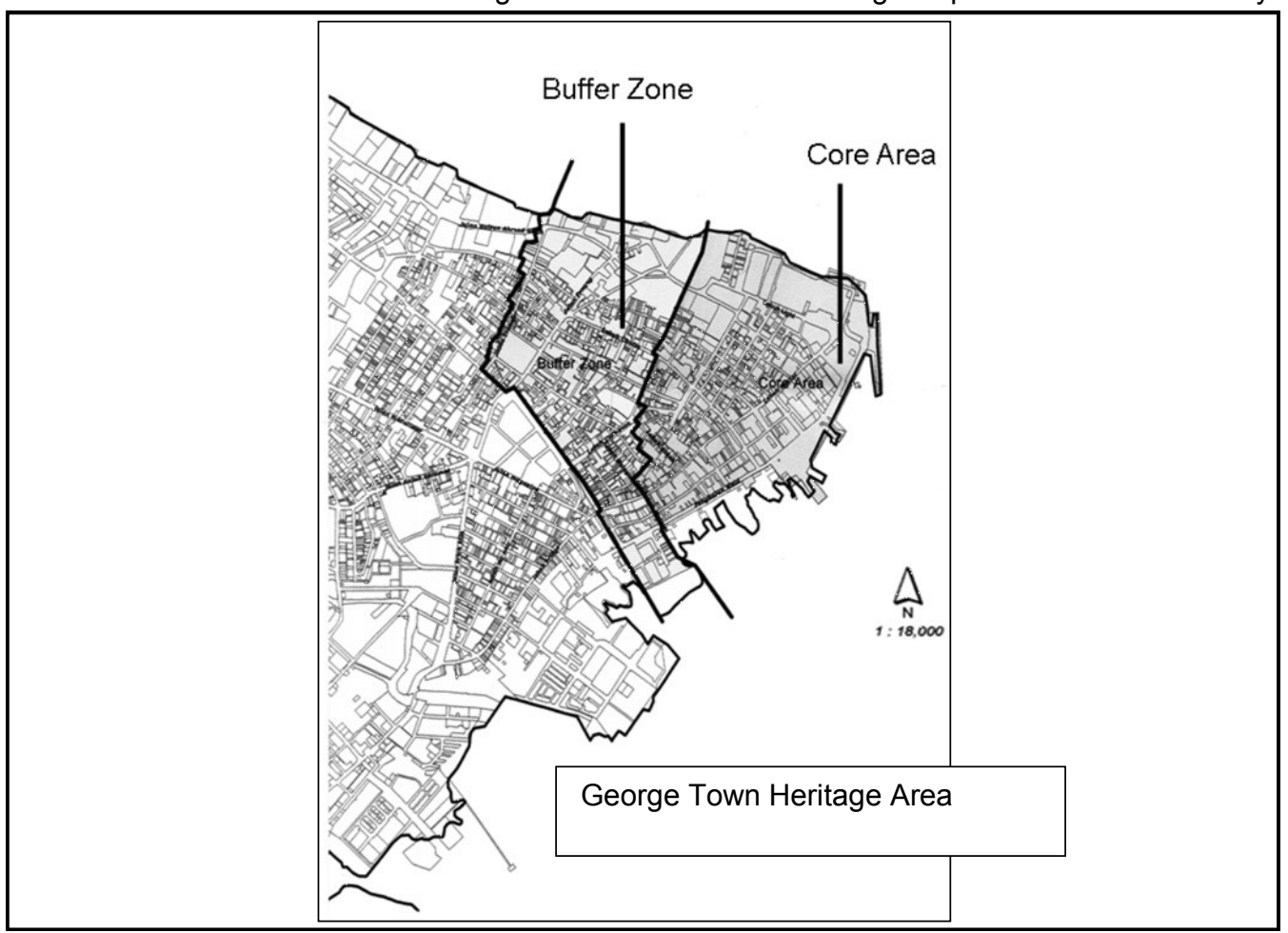

Fig. 1 - Core and Buffer Zones of George Town World Heritage Site Source: Lee et al. (2009)

of George Town. Many George Town residents and businesses have left the inner city in droves. In turn, this has caused George Town to fall into decline with many abandoned and dilapidated buildings where home owners are uninterested to maintain them due to the inability to rent their properties out after the repeal of the Act (Lim et al. 2008).

All these changed when George Town was inscribed as a UNESCO World Heritage City on 7 July 2008. The entire city immediately experienced a 'renaissance' (i.e. rebirth) and spruced into a regeneration mode with renewed interest to move people, businesses and other socio- 
cultural activities back into the inner city. In tandem, the dilapidated properties in the inner city are now considered as 'cash cows' that are marketable, tradable and deemed valuable assets to both local and foreign investors alike. To some quarters, this scenario of property tradability and reinvestment might be taken as reaping the benefits from a successful urban regeneration initiative. However, amidst all these transformations necessitated by the UNESCO listing, inevitably, this calls into question the voices, the participation and the aspirations of the George Town residents themselves in the process of planning and conserving their city. Besides the Government, effective planning policies would require integrated and strategic partnership, co-operation and participation by all stakeholders (Lim et al. 2008, Peerapun 2012). In essence, a bottom-up approach with extensive community participation is the way forward.

Specifically, this study is an extension of a similar project that was undertaken in 2006 prior to George Town's listing as a UNESCO heritage city. The findings from the earlier study revealed that the community was neither consulted nor were their preferences sought when the Penang State Government (2011) was applying to be listed as UNESCO's World Heritage City back in 2005. This indicated that the voices of the inner city residents were not heard and acknowledged in the planning process. Thus, this study aims to build on and extend from this previous research by enquiring and revisiting these similar concerns four years after George Town has been inscribed as a UNESCO Heritage City. Undoubtedly, this inscription has accelerated the need to hasten the processes of conservation and preservation of physical as well as socio-cultural environments of George Town to protect the Outstanding Universal Values of the city. These are processes that cannot and should not be undertaken by only the government without consulting other stakeholders. Heritage conservation may bring potential gains for heritage property investment but conservation work requires cooperation from and among all property owners. Public relation, consensual commitment and unwavering support from all stakeholders are vital towards successful urban conservation.

Before the listing, conservation was not popular in this city because of low public awareness (Holland 2001) due to the fact that most residents do not actually know what is heritage or the importance of conservation. It is because of this that most developers often choose to clear the whole site to carry out redevelopment rather than restore or rehabilitate old buildings. One of the main challenges for towns attempting to conserve heritage properties is to strike a balance between the protection of historical homes and the individual rights of property owners (Mclnnis 2001). Thus, good public understanding about the importance of heritage to the community is vital to encourage participation from the community. Therefore, this extended study aims to explore, examine and understand the residents' attitudes and preferences in the urban planning of George Town as a Heritage City after the UNESCO listing.

In an overview, this paper is divided into five sections. Section one introduces the background and research aim of this study. Section two reviews the relevant literature on sustainable urban conservation and the community's awareness, experience, appreciation and perception of their urban environment in the planning process whilst section three briefly outlines the methodology of this study. The key findings will be discussed in section four and section five highlights some of the issues encountered after George Town was inscribed as a UNESCO heritage city.

Finally, section six concludes this paper by suggesting some pragmatic policy implications towards more sustainable urban conservation in George Town.

\section{Literature Review}

Recently, issues related to heritage preservation and management, especially those referring to sustainability of a historical city, are closely tied to topics and theories of participation of citizens in the city (Adeniran and Akinlabi 2011). It is widely accepted that sustainable 
development of cities depends greatly on the functions of public participation (Azman et al. 2010). Public participation is currently regarded as a key to conflict resolution and sustainable development (Sirisrisak 2009). The 2008 revision of UNESCO's Operational Guidelines for the Implementation of the World Heritage Convention explicitly recognizes the need for local participation in heritage management with the addition of a fifth organizational strategic objective: "Enhance the role of communities in the implementation of the World Heritage Convention" (UNESCO 2008).

Recognizing the difficulty in identifying, understanding and protecting heritage features without the input of its cultural owners, a philosophical shift involves an increased focus upon community participation from the part of cultural heritage managers (Grimwade and Carter 2000, Hodges and Watson 2000, Smith et al. 2003). Mire's (2007) study of heritage management in Somalia provides an example of this reality where she finds that sustainable management of Somali heritage resources is dependent upon the inclusion of local perspectives, knowledge systems and management techniques.

Participation enhances access to and ensures greater transparency in the decision-making process in both local governance and resource management (Nabwire and Nyabenge 2006). The advantages of community participation are manifold. Among them are the ability to obtain a more accurate understanding of the needs of the community, an improved ability to adapt the project to meet the local conditions and an improved spirit of cooperation both within the community itself and between the community and outside stakeholders (La Frenierre 2008).

The level of participation in any development or planning project is immediately driven by the locals' perceptions and locals' attitudes towards the project. Although communities express support for tourism development associated with events, many local residents are also concerned with the associated inconveniences such as traffic congestion, crime and overcrowding (Twynam and Johnston 2004) as well as noise pollution, parking difficulties, crime and increase of the cost of living (Bob and Swart 2009).

The study on the residents perception of mega impacts (Kim and Petrick 2005, Adriaanse 2007) shows that it is advantageous to allocate more resources to effectively increase residents' perceived positive impacts and at the same time reduce their perceived negative impacts. In studies focusing on urban green spaces (Jim and Chen 2006), Jupp et al. (2002) expressed that studies to explore the mind-set of stakeholders could allow cities to build spaces that are socially inclusive rather than just spaces to serve narrow segments of the population.

Based on a series of studies carried out by Spennemann (1992), Spennemann and Harris (1996) and Spennemann et al. (2001), there are substantial differences between the values held by the heritage professionals and those held by the community in historic preservation. According to Spennemann (2003), the education of the public about the need of historic preservation is one of the main strategies in historic preservation. Stephenson et al. (2004) in Bannockburn Heritage Landscape Study discovered that people are unlikely to protect or care for places unless they perceived the importance of the places. Undoubtedly, people's attitude towards heritages immediately affects the sustainability of any heritage conservation project.

People's awareness, experience, appreciation and perception of their urban environment are essential dimensions of urban design (Carmona et al. 2003). This could be seen in the study of the Vietnamese Australians' perception towards national parks which provides an insight into the attitude of people towards heritages, in which many Vietnamese people perceived national park as peaceful contrasts to the stresses of working lives and cities, a place for recreation that provides leisure and serves as an important venue for religious and scouting activities (Thomas 2002: 126). Therefore, this explains their support for provision of parks. The same could apply 
to conservation of heritage city. If the perception of the residents is positive, the support of the people will make the conservation effort a success.

According to Assari et al. $(2011,2012)$, the success of heritage conservation and development in a historical city mainly depends on two set of factors: 1) Awareness, participation and appreciation towards heritage values and its economic potential; and 2) Education programs designed for each historical cities. There are these two factors that this paper will look into to have an idea of the success of George Town efforts in conservation since 2007. All the concepts that are discussed above are encapsulated in the diagram shown in Figure 2 below.

\section{Material and Methods}

According to Adler and Clark (1999), people who are involved in or are affected by a programme are called stakeholders. Their perspectives are important to help influence and determine appropriate strategies in shaping efficient planning for urban development (Potter 1985, Chetwyn 1999). In other words, by studying the perspectives of the stakeholders, we can capture the picture of a development issue and the real needs of the community involved. In this way, constructive solutions or alternatives can be formulated to meet their needs.

In the case of George Town, although various programmes have been implemented, the

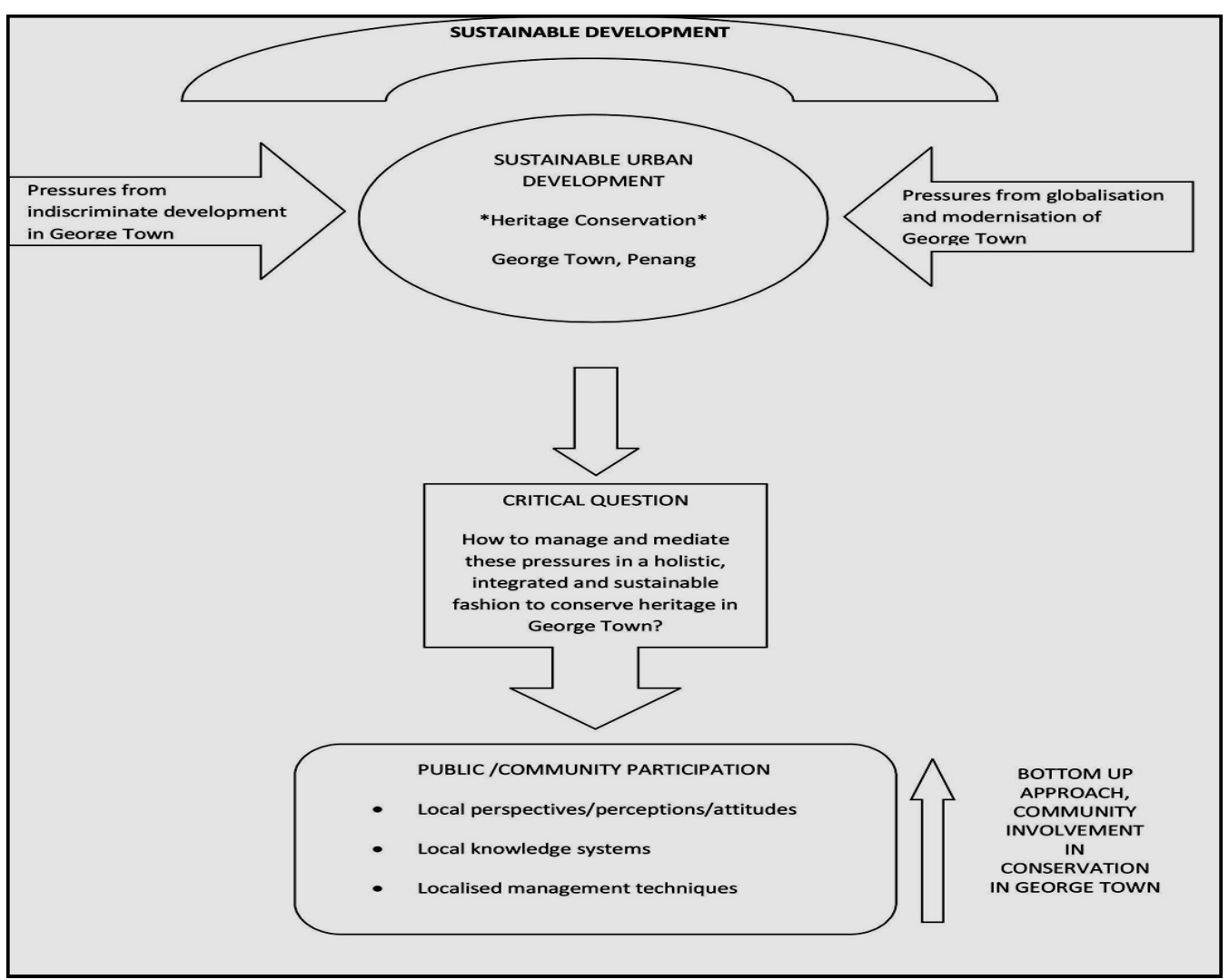

Fig. 2 - Conceptual Framework of the Study 
impact of these activities and programmes are not known as there is no study on the residents' perspectives on the conservation of George Town after the UNESCO inscription. Without constant feedback from the community, it is difficult to assess whether the programmes conducted are achieving its objectives. Therefore, as a quick evaluation of the perspectives of the stakeholders four years after the inscription, a "before" and "after" comparison was conducted. The data for the "before inscription" was based on a previous survey undertaken in 2006. The data for the "after inscription" was collected from a survey conducted in 2012 . The framework of the current survey was based on the previous survey to enable an "apple to apple" comparison.

Following the previous survey, we identified our target of survey to be the 'residents' from three administrative districts, namely George Town 1, George Town 2 and George Town 3. According to MPPP (Municipal Council of Penang Island) Design Guidelines for Inner City of George Town 1987, George Town 1, and a part of George Town 3 are designated as conservation areas, which consists of the core area and buffer zone, while George Town 2 is located at the boundary of the conservation area. The objective of the survey was to obtain the awareness/preferences of George Town's residents regarding urban conservation activities that have been carried out in the heritage area of George Town.

To achieve our objective, the questionnaire survey method was used as it is an established method to obtain information from the target population about their attitudes, behaviours, thoughts and opinions through a set of standardised questions (Moser and Kalton 1979, Adler and Clark 1999, Lanthier 2002, Wates 2002). A structured interview approach was adopted for the survey. This method was adopted to mitigate the problem of non-response due to illiteracy in English as most of the residents in the survey area were either elderly people or educated in Chinese medium schools. Furthermore, the structured interview method used a standardised interview schedule where data were collected from a sample of population based on a same set of predetermined questions (Adler and Clark 1999); and this will help to ensure uniformity in the questions asked although the study used several interviewers/enumerators to cover the 400 samples.

The sampling frame used in the survey mirrors the sampling frame used in the earlier study. This is done deliberately because the new study intends to find out if the preferences of the residents have changed since 2006 and to obtain a comparable study, the same samples were used. The samples were derived from the sampling frame compiled from the Assessment List 2005 that was obtained from the local authority. It contained the complete addresses of all the properties in the study area. The target respondents were the heads of households or their representatives who were staying in George Town (residents) at the time of the survey. In order to cover most of the residents in the study areas, the research team decided to select residents from four types of buildings, namely house, shop, shop-house and apartment/flat. Offices and warehouses were excluded from the survey. The samples were then selected from the sampling frame using the simple random method. At the confidence level of $95 \%$, a sample size of 400 was determined for this survey.

The questionnaire used in this survey was designed based on the previous questionnaire. The style of the language and the format of the questions were maintained as it has been proven in the previous study that the respondents were able to understand and answer the questions. Although some questions were replicated in this study, the majority of the questions were designed to explore and understand the current awareness and preferences of the residents of George Town.

However, due to a lapse of 6 years since the previous study, some of the respondents were no longer in the area. Some of the samples have relocated or passed away. There were also cases where the building of the previous samples had been demolished. In order to maintain 
the sample size, the unavailable samples were replaced by new samples using the convenient sampling method. The interviewers were told to interview the neighbour of the sample that was no longer available. The interviewers selected to conduct the survey were fluent in both English and Chinese languages as well as local dialects (i.e. Hokkien, Cantonese) to ensure that there were minimal language problems while conducting the survey interviews. In order to ensure a good response rate, the interviewers also visited the site during and after the working hours.

In this survey, the respondents were from three main groups, namely tenants $(45 \%, 180)$, owners $(37 \%, 150)$ and others $(18 \%, 70)$. Both owners and tenants were quite proportionately represented in the survey. Most of the respondents (245 persons) were between 31 to 60 years old (Table 1). In terms of education level, Table 2 shows that the majority of the respondents received only up to secondary level of education $(60 \%, 240)$. This percentage mirrored the situation back in 2006 where those with secondary education also scored the highest percentage. In the 2012 survey, only a very small percentage $(6 \%, 24)$ of the respondents received university degree education. Respondents under the category of 'other' $(2 \%, 8)$ represented those with higher education qualifications such as postgraduate degrees and professional qualifications. This indicates that the population with secondary level education are still residing in the heritage areas in George Town and this creates a pocket of lower income residents in the heritage areas.

\section{Results and Discussion}

In order to examine the residents' awareness and appreciation towards the heritage values and their economic potentials, the survey investigated the respondents' concerns on the importance of protecting historic buildings and their willingness to pay more for a heritage property. In the real estate market, people are usually willing to pay more for a property which has a promising value for investment. In some scenarios, people will pay more for a property which is meaningful or important to them.

\section{Importance to Protect Historic Buildings}

The study in 2006 reported that $71 \%$ of the respondents indicated it was important to protect historic buildings while $13 \%$ said otherwise (Fig. 3). The remaining $16 \%$ indicated that they have no opinion on the subject. This survey undertaken six years later revealed that historic

Respondents' Age Group for Surveys in 2006 and 2012

Table 1

\begin{tabular}{|l|r|r|r|r|}
\hline \multirow{2}{*}{ Age Group (years) } & \multicolumn{2}{|c|}{ Survey in 2006 } & \multicolumn{2}{c|}{ Survey in 2012 } \\
\cline { 2 - 5 } & Count & \multicolumn{1}{c|}{$\%$} & \multicolumn{1}{c|}{ Count } & \multicolumn{1}{c|}{$\boldsymbol{~}$} \\
\hline$<21$ & 8 & 3 & 24 & 6 \\
\hline $21-30$ & 48 & 18 & 58 & 14 \\
\hline $31-40$ & 60 & 22 & 83 & 21 \\
\hline $41-50$ & 74 & 28 & 82 & 20 \\
\hline $51-60$ & 50 & 19 & 80 & 20 \\
\hline $61-70$ & 21 & 8 & 50 & 13 \\
\hline$>70$ & 8 & 3 & 23 & 6 \\
\hline TOTAL & $\mathbf{2 6 9}$ & $\mathbf{1 0 0}$ & $\mathbf{4 0 0}$ & $\mathbf{1 0 0}$ \\
\hline
\end{tabular}

Source: Fieldwork surveys, 2006 \& 2012 
Respondents' Educational Level for Surveys in 2006 and 2012

\begin{tabular}{|l|r|r|r|r|}
\hline \multirow{2}{*}{ Educational Level } & \multicolumn{2}{|c|}{ Survey in 2006 } & \multicolumn{2}{c|}{ Survey in 2012 } \\
\cline { 2 - 5 } & Count & \multicolumn{1}{c|}{ \% } & Count & \multicolumn{1}{c|}{$\%$} \\
\hline None & 23 & 9 & 23 & 6 \\
\hline Primary & 52 & 19 & 51 & 13 \\
\hline Secondary & 141 & 52 & 240 & 60 \\
\hline Certificate & 17 & 6 & 16 & 4 \\
\hline Diploma & 20 & 7 & 38 & 9 \\
\hline Degree & 14 & 5 & 24 & 6 \\
\hline Other & 2 & 1 & 8 & 2 \\
\hline TOTAL & $\mathbf{2 6 9}$ & $\mathbf{1 0 0}$ & $\mathbf{4 0 0}$ & $\mathbf{1 0 0}$ \\
\hline
\end{tabular}

Source: Fieldwork surveys, 2006 \& 2012

buildings have become even more important to the residents. As shown in the same figure, $83 \%$ of the respondents of the survey in 2012 indicated that it is important to protect the historic buildings. This shows an increase of $12 \%$ from the previous survey. Currently, only $6 \%$ said it is not important to them as compared to $13 \%$ in 2006 . The current finding augurs well for the historic city of George Town as this means that more residents now appreciate the historic buildings as compared to six years ago. This could also imply that the awareness programmes and other heritage based activities have positively influenced the perspectives of the residents towards the historic buildings.

The survey also tried to dissect further the categories of respondents that find it important to protect the historic buildings. Again, the survey found that all three categories of 'owner', 'tenant' and 'others' (workers/owner's relatives) unanimously agreed that it is important to protect the historic buildings as shown in Figure 4 below.

Referring to Figure 5, the results from the 2006 survey showed that those people having the highest awareness for protecting historic buildings were those people with higher levels of education. Amongst university degree holders, more than $90 \%$ of the people considered urban heritage as being important to them. This may be due to the fact that the better educated group

was more exposed to literature and publicity related to the urban heritage. As compared with the 2006 survey, obviously, the 2012 survey shows arising appreciation on historic buildings among all groups except the respondents with degree and those without formal education attainment. More than $80 \%$ of the respondents with primary and secondary education, as well as certificate and diploma holders now opined that it is important to protect historic buildings. Nevertheless, degree holders no longer hold protection to historic building as important as in the 2006 survey. It is interesting to note that all respondents under the category of 'other', which comprises of those with postgraduate degree or professional qualification, opined that it is important to protect the historic buildings. This could be due to their greater awareness of the benefits of heritage conservation. Based on the findings from the 2012 survey, the level of appreciation in historic buildings has increased across all the levels of education while the lack of education is still a barrier to the conservation of historic buildings.

\section{Willingness to Pay More for Heritage Properties}

The study also attempted to find out the willingness to pay higher for historic buildings by the respondents. Referring to Figure $6,40 \%$ of the respondents of the 2006 survey were willing to 


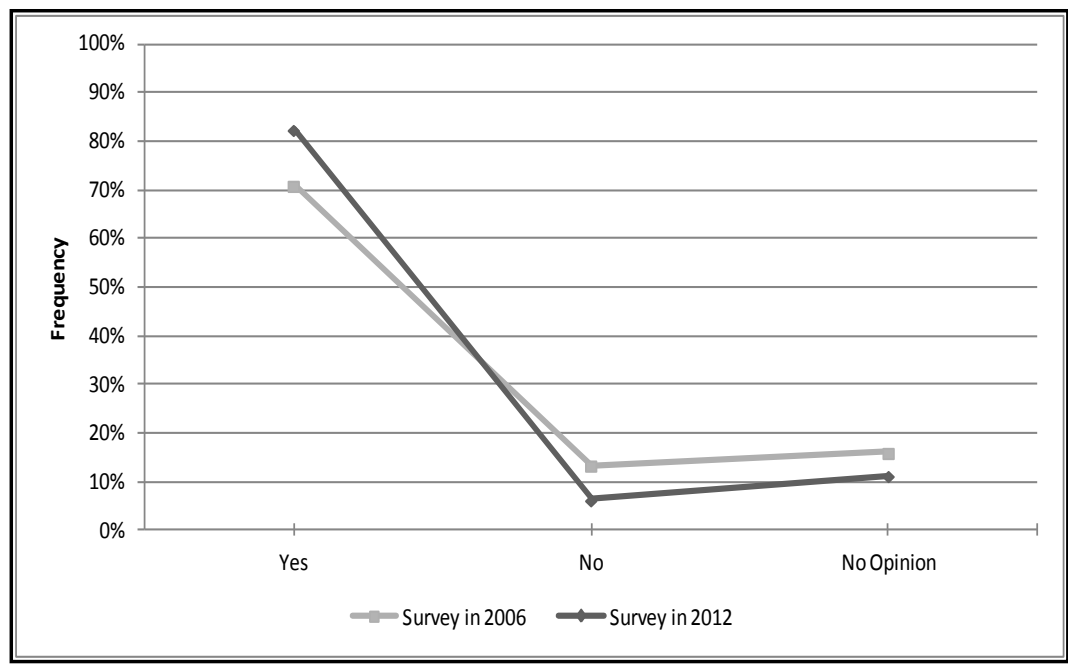

Fig. 3 - Opinion about the Importance to Protect Historic Buildings Source: Fieldwork surveys, 2006 \& 2012

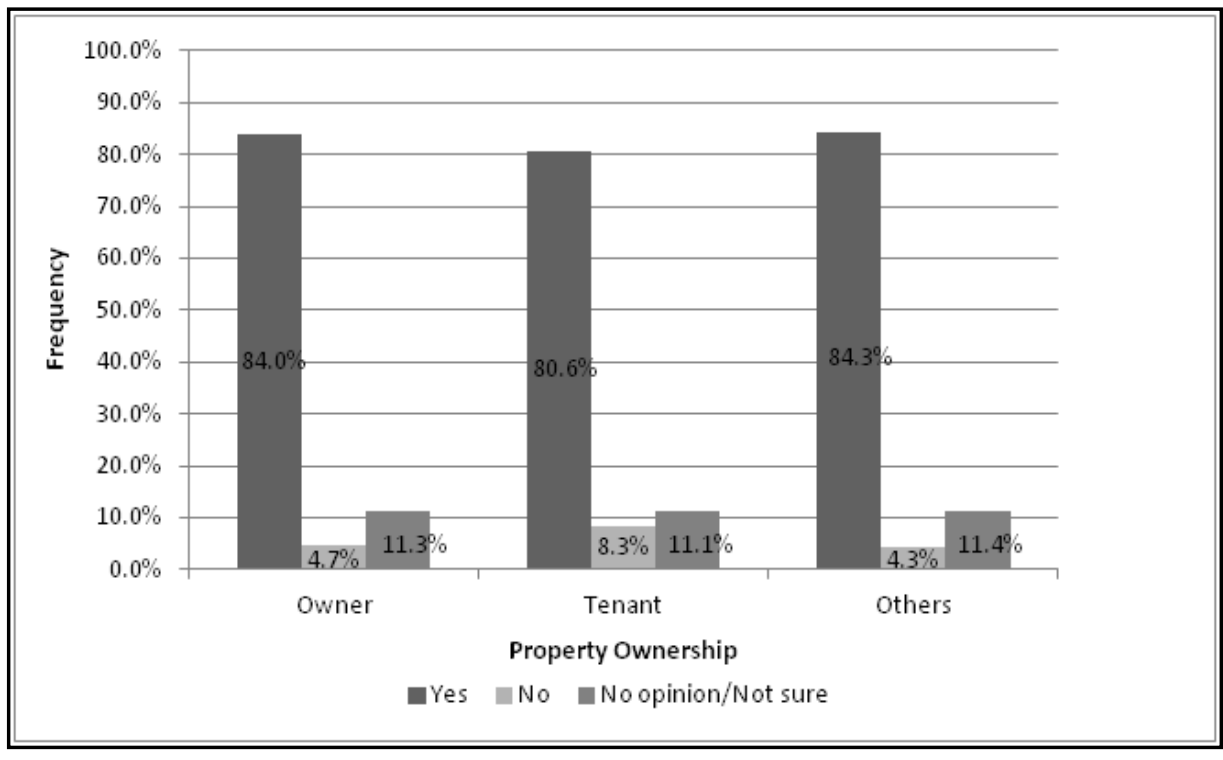

Fig. 4 - Opinion about the Importance to Protect Historic Buildings, by Property Ownership (2012)

Source: Fieldwork survey, 2012

pay more for heritage properties while 45\% were not. The 2012 survey showed that the percentage of the respondents that were willing to pay more has decreased slightly from $40 \%$ in 2006 to $37 \%$ in 2012 . However, this did not translate into the market price for historic buildings as historic property prices has been increasing since 2006. As reported by Wong 
(2012) in The Star Online recently, the cost of buying a pre-World War II shophouse in George Town has now reached RM 2,000 per square foot which is equivalent to the price of the most luxury KLCC condominium units. Before the UNESCO listing in the year 2008, pre-war shophouses in Penang were generally about RM 200,000 to RM 800,000 depending on size and location. The contradictory findings from the survey in this subject revealed that typical local residents from the inner city of George Town do not share the same views with the local or international investors. They in fact value the heritage buildings differently, either simply due to their different preferences on the types of property or the lack of awareness and confidence

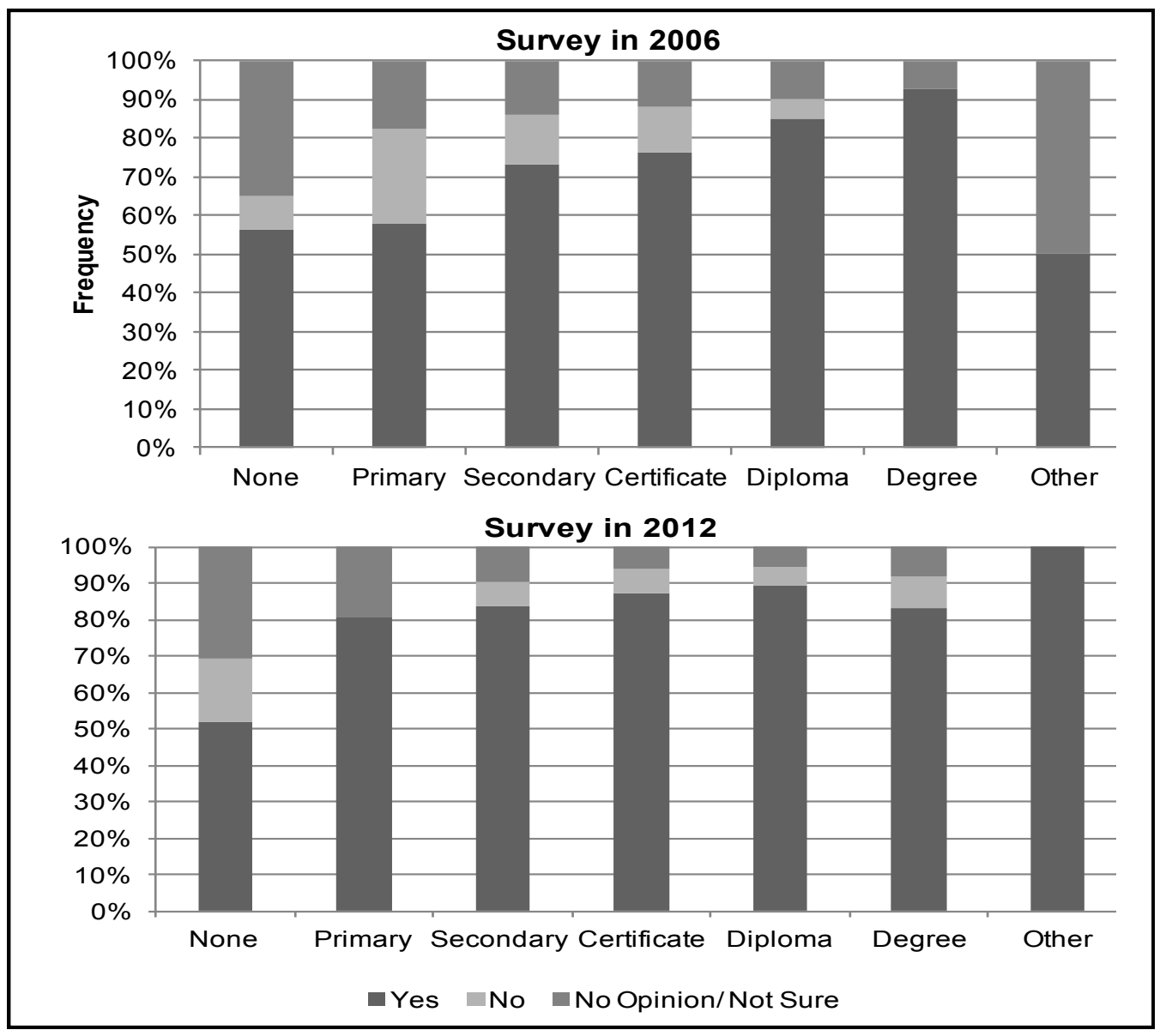

Fig. 5- Opinion about the Importance to Protect Historic Buildings, by Level of Education

Source: Fieldwork surveys, 2006 \& 2012

on the potential economic value of the heritage buildings.

In addition, this study also compared the willingness to pay for heritage buildings between the tenants and owners. In 2006, more than half (55.8\%) of the tenants were willing to pay for heritage buildings if they were to buy a property in George Town. The amount was higher than the percentage of property owners $(39.6 \%)$ who were willing to pay for heritage buildings (Tan 
and Fang 2007).

In the 2012 survey, as shown in Figure 7, the situation has reversed and now it is the owners $(42 \%)$ who are more willing to pay more as compared to the tenants $(35 \%)$. It seems that the increase in awareness and appreciation of historic buildings in the last six years has increased the willingness of owners to pay higher. This could also be due to the benefits that the owners may have received or anticipated to receive, such as grants from the government agency to conserve their properties.

Comparing the education level and willingness to pay, the 2012 survey found that the respondents with postgraduate and professional qualification (listed under 'Other') were most willing to pay more $(50 \%)$ while those with secondary school qualification $(35 \%)$ were at least willing to pay more followed closely by diploma holders (37\%) as shown in the Figure 8 below.

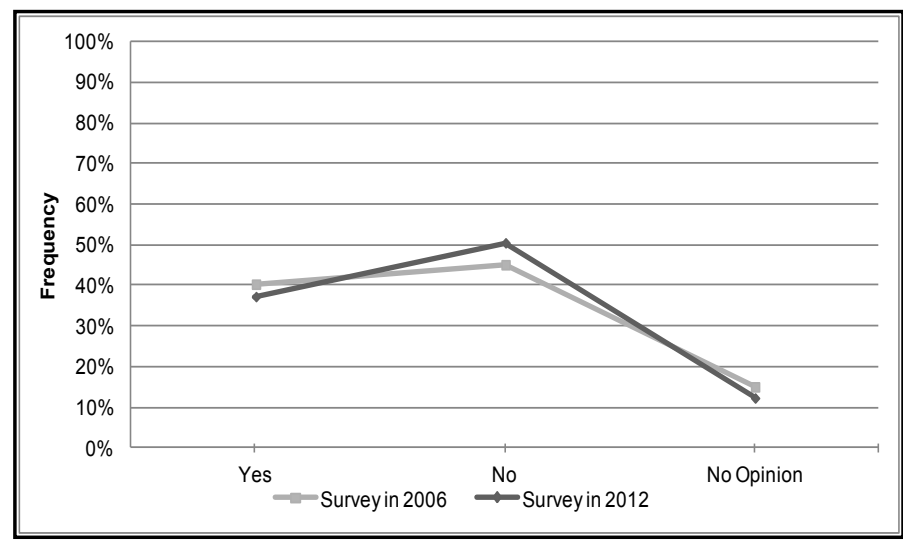

Fig. 6 - Willingness to Pay More for Historic Buildings Source: Fieldwork surveys, 2006 \& 2012

This finding suggested that those highly educated tend to be more confident to invest in heritage properties as they are well aware of the positive effects of UNESCO listing brought to the market value of heritage properties. Nevertheless, those without formal education registered the third highest percentage $(43.5 \%)$ in willingness to pay more for a heritage building. The respondents without formal education were possibly the older generation who have spent most of their lifetime in a heritage house at the site. Their strong affection to the traditional and cultural elements of a heritage building makes them willing to pay more for it.

\section{Preference between Heritage and Modern}

To elicit the local residents' preference between a heritage city and a modern city, this study examined the respondents' preference to develop George Town into a modern city. Besides, the survey also enquired the respondents' preference in selecting the types of houses (heritage house or modern house). A person's preference for a heritage city does not necessarily translate into a similar preference to live in a heritage house. Likewise, it is not surprising to note that some people may be fond of a heritage house that is located in a modern city.

\section{Heritage City versus Modern City}

When being asked whether they wanted George Town to be developed into a modern city, the majority of the respondents $(64 \%, 257)$ said "No" to a modern city whilst one third $(34 \%, 137)$ 
stated that they preferred a modern urban environment (Fig. 9). Interestingly, this finding differed from the earlier study in 2006 where more than half $(52 \%)$ of the respondents back then opted for a modern vertical city as opposed to less than half $(45 \%)$ that preferred a historic town (Fig. 10). Arguably, the change in preference could be motivated by the inscription of George Town in the UNESCO Heritage List in 2008.

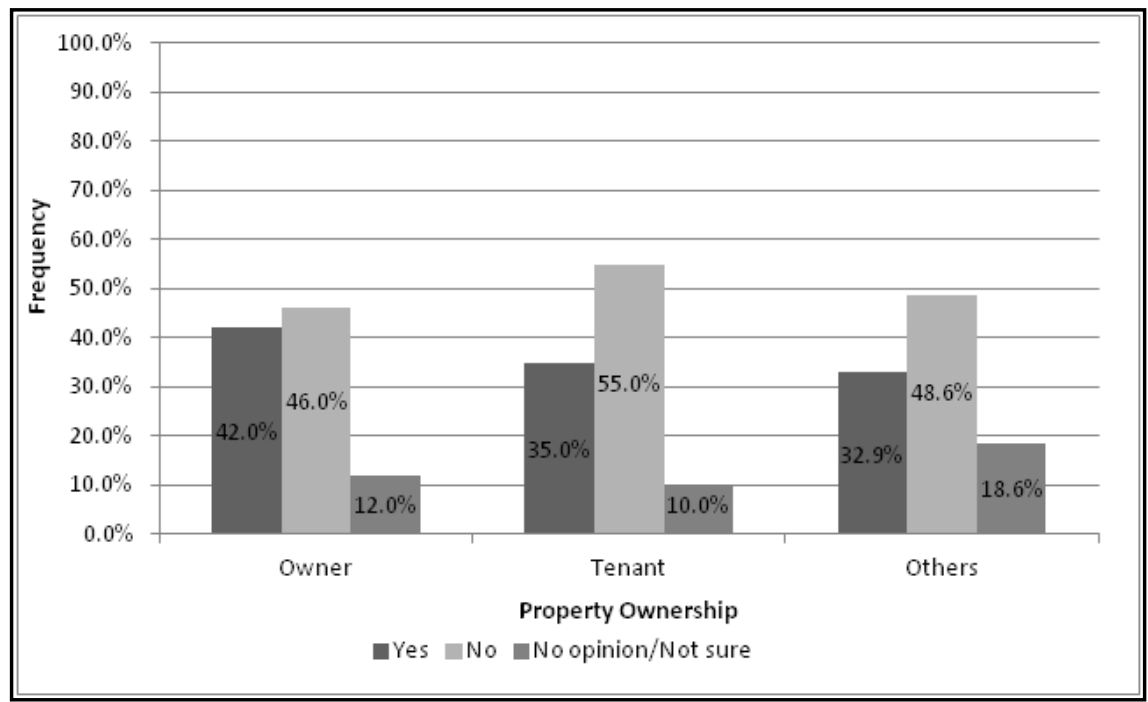

Fig. 7 - Willingness to Pay More for Historic Buildings, by Property Ownership (2012) Source: Fieldwork survey, 2012

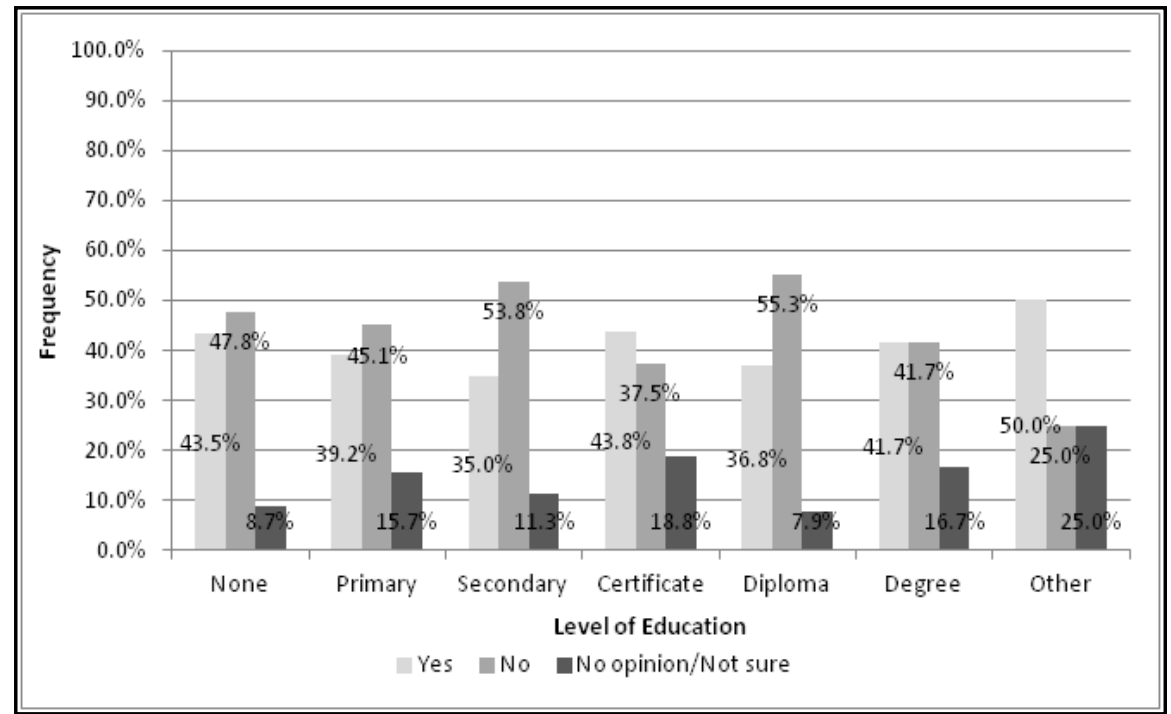

Fig. 8 - Willingness to Pay More for Historic Buildings, by Level of Education (2012) Source: Fieldwork survey, 2012 
Based on the findings from the 2012 survey, generally, non-owners (i.e. tenants, others) preferred to develop George Town into a modern city compared to the owners themselves, as shown in Figure 11. This could be due to a strong sense of sentiment by the property owners to retain the status quo.

Age was also another critical factor that determined the preferences of the respondents. Both the surveys in 2006 and 2012 found that the younger generation preferred George Town to be developed into a modern city. In 2012 , about $46 \%$ of those below 21 -years-old favoured this idea. On the other hand, the older generation (> 70 years old) was less favourable of this idea. Only $12 \%$ of the people preferred a modern city.

\section{Heritage House versus Modern House}

In the 2012 survey, when enquiring their preferences to live in a modern house or heritage house, it was found that more than half $(54 \%)$ of the owners preferred heritage houses (Fig. 12). The situation was almost similar for the tenants while approximately $50 \%$ of them also opted for heritage houses. Amongst home owners, a tiny percentage (4\%) expressed their preference for both types of houses. In fact, the findings showed an almost equal split between their respective preferences for home owners.

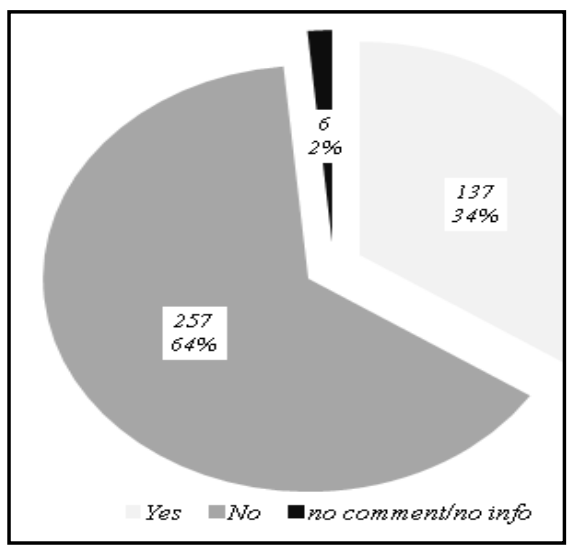

Fig. 9 - Preference to Develop George Town into a Modern City (2012)

Source: Fieldwork survey, 2012

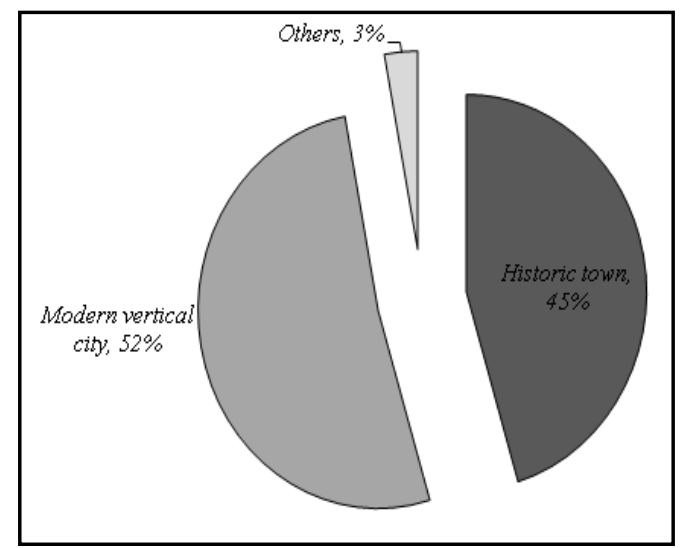

Fig. 10 - Preferred City for Residency (2006) Source: Fieldwork survey, 2006

Further analysis revealed that the age factor influenced again the choice of the house a person chose to live. Again, both the 2006 and 2012 surveys recorded the same findings. It is clearly reflected that the younger generation was not very keen to live in heritage houses if compared to their older counterparts. In 2012 , only slightly more than a quarter $(29 \%)$ of those below 21 years-old preferred heritage houses. It is observable that the preference for heritage houses increased with a person's age. For instance, in the 51-60 age group, preference for heritage houses rose to $53 \%$ and the percentage continued to hike to almost $70 \%$ especially amongst those above 70 years of age. This could be due to the nostalgic sentiments that the older generation harbour towards their heritage houses. Educational attainment inadvertently also shaped a person's choice of house. Though the study in 2006 suggested that education could be the key to successful conservation efforts, however, an educated person's heritage and conservation knowledge and appreciation does not necessarily mean that they will choose to live in a heritage house. Like in 2012 survey, it is interesting to note that it was those 
Yoke Mui LIM, Suet Leng KHOO, Kean Siang CH'NG

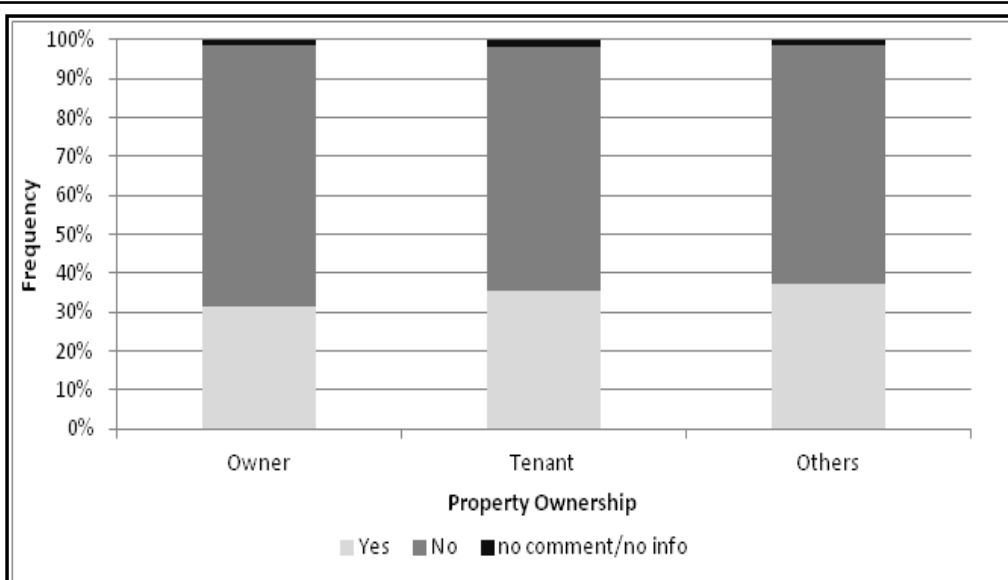

Fig. 11 - Preference to Develop George Town into a Modern City, by Property Ownership (2012)

Source: Fieldwork survey, 2012

respondents without any formal education (82\%) that preferred heritage houses compared to their more educated counterparts. Less than one third $(31 \%)$ of diploma holders opted for heritage houses and a slightly higher percentage of about $41 \%$ of degree holders preferred heritage houses (Fig. 13). The general picture depicted that those with higher education tend to prefer modern houses despite having more heritage knowledge and awareness.

\section{Discussions}

The above findings show that a higher education would increase the level of appreciation for heritage buildings but it does not translate into willingness to own and live in one. In George

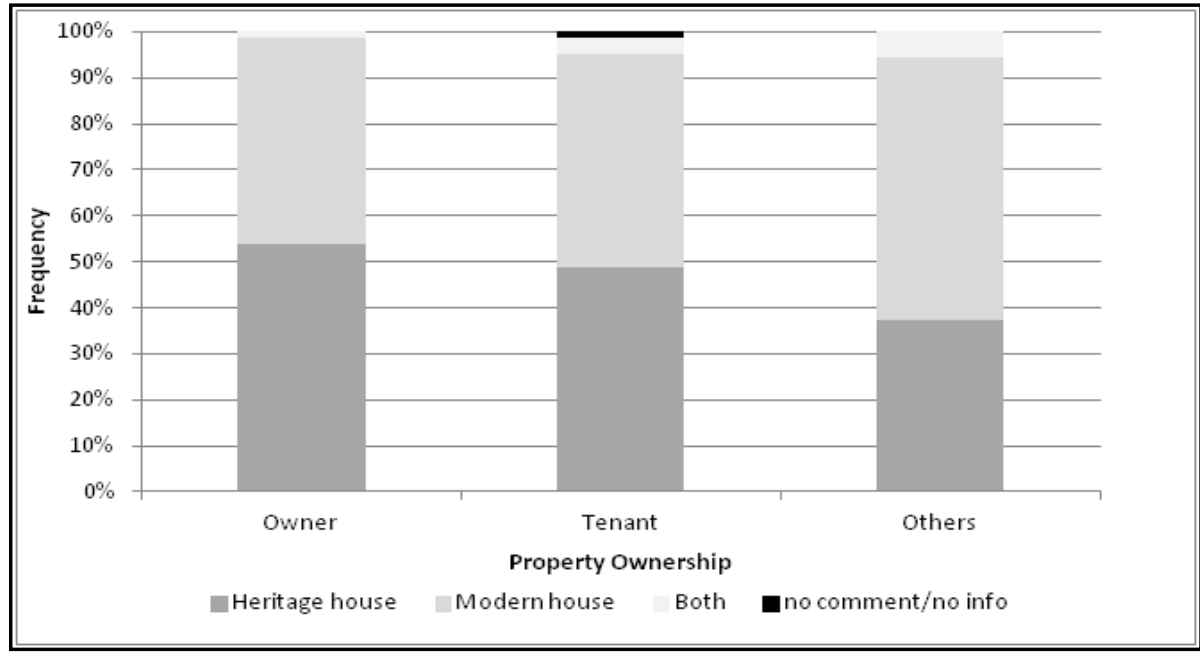

Fig. 12 - Preference to Stay in Modern House or Heritage House, by Property Ownership (2012)

Source: Fieldwork survey, 2012 
Town, its residents are mainly in the lower income group, as shown in the findings of this survey under the section on education level. These residents continue to stay put as they could not afford the expensive modern houses in the other parts of the island. However, as mentioned earlier in this paper, property prices have soared due to the demand from external investors and many owners are selling out as this is an opportunity for them to afford modern housing. In view of this, the people of Penang (the state which George Town is the capital) is now concerned that if the selling continues, one day the city of George Town may not belong to the people of Penang but to foreign investors. Currently, this is one of the challenges faced by the city of George Town. With the influx of foreign investors bringing in the new culture and lifestyle, would this ruin the intangible heritage which George Town is recognised for? Conservationists are foreseeing this and they are working hard to arrest the situation.

However, at the moment, there is no specific restriction by the local authority in curbing the purchase of heritage properties by foreign investors. Market forces prevail and owners are very much tempted to sell as it is now very profitable to do so. If the owners do not sell, they face problems in repairing and maintaining the property. The owners' main grouse is the lack of funds as heritage properties require maintainance and repairing constantly to upkeep the property to the standard required by the authority. The survey shows that $66 \%$ of the respondents mentioned that they lack funds to conserve and repair their properties (Table 3).

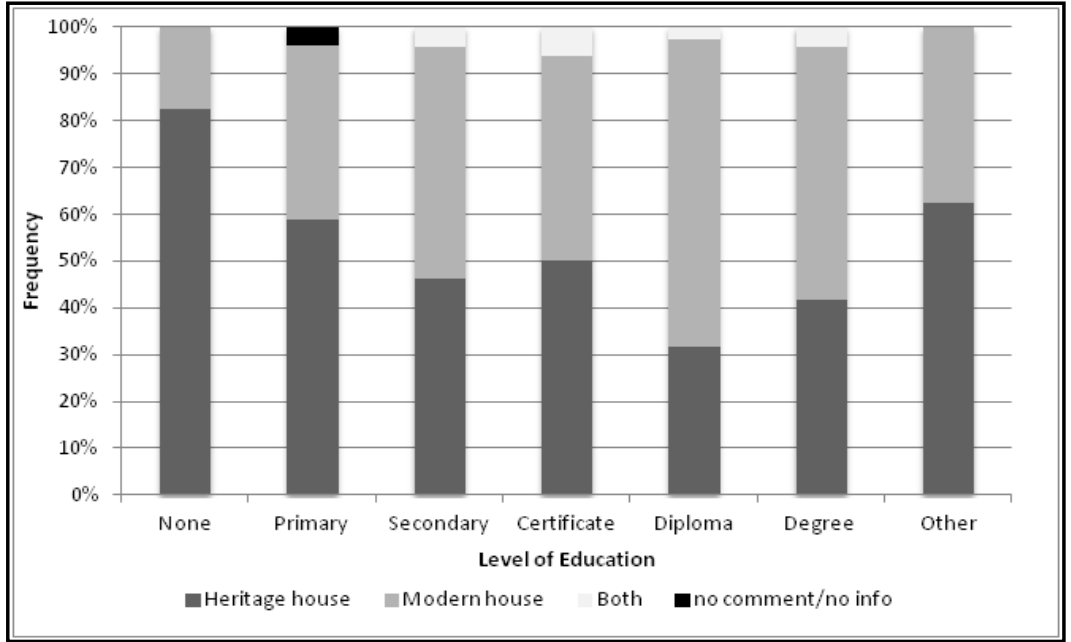

Fig. 13 - Preference to Stay in a Modern House or Heritage House, by Level of Education (2012)

Source: Fieldwork survey, 2012

This financial problem is compounded by the fact that the residents are from the lower income group and yet the cost of repairs are high due to specialised work and materials needed to maintain heritage houses.

In terms of funding, the Malaysian Government has intervened through its conservation arm, Think City Sdn Bhd, to disburse subsidies to heritage home owners. An allocation of RM 20 million has been allotted by the Malaysian Government to subsidize conservation works. Private property owners can submit their conservation proposals and budgets for consideration by Think City. Amongst the criterion stipulated to evaluate the grants are as follows: 1) contribution to the Outstanding Universal Value (OUV) stipulated in George Town's Special Area Plan (SAP); 2) contribution to a sustainable city and 3) improvement towards social and 
economic conditions. Generally, grants will be disbursed depending on the quantity of works, the proposed use of the building and the contribution to the aforementioned criterion of the OUV. Applicants will apply for this grant on a competitive basis.

The survey further shows that other than funding, the residents have no problem in seeking information on heritage and conservation of heritage buildings. This is in part due to the efforts of George Town World Heritage Incorporated, the body responsible for the management, monitoring and promotion of the city of George Town as a World Heritage Site, various pro-heritage non-government organisations (i.e. Penang Heritage Trust) and the news media in constantly creating awareness and technical support programmes to educate and assist the residents in the heritage areas.

\section{Conclusion}

In conclusion, the objective of revisiting the awareness of residents of George Town on issues of conservation has been met through the conducted survey. A comparison of the current findings with a similar survey conducted in 2008 provides insight into the perception of the

Issues Post Inscription

Table 3

\begin{tabular}{|l|r|r|r|r|r|}
\hline Immediate Issues/Problems & \multicolumn{1}{|c|}{ Yes } & Yes (\%) & No & No (\%) & TOTAL \\
\hline $\begin{array}{l}\text { Lack of funds to conserve \& repair } \\
\text { property }\end{array}$ & $\mathbf{2 6 3}$ & 65.8 & 137 & 34.3 & 400 \\
\hline $\begin{array}{l}\text { Lack of funds to maintain property } \\
\text { (after conservation) }\end{array}$ & $\mathbf{2 0 0}$ & 50.0 & 200 & 50.0 & 400 \\
\hline $\begin{array}{l}\text { Lack of technical knowledge } \\
\text { to conserve \& repair property }\end{array}$ & 119 & 29.8 & 281 & 70.3 & 400 \\
\hline $\begin{array}{l}\text { Lack of technical knowledge } \\
\text { to maintain property (after conservation) }\end{array}$ & 84 & 21.0 & 316 & 79.0 & 400 \\
\hline $\begin{array}{l}\text { Lack of knowledge about which formal } \\
\text { institution to approach \& consult }\end{array}$ & 78 & 19.5 & 322 & 80.5 & 400 \\
\hline Lack of heritage awareness & 95 & 23.8 & 305 & 76.3 & 400 \\
\hline $\begin{array}{l}\text { Unsure about what to do } \\
\text { with heritage property after listing }\end{array}$ & 60 & 15.0 & 340 & 85.0 & 400 \\
\hline Others & 48 & 12.0 & 352 & 88.0 & 400 \\
\hline
\end{tabular}

residents regarding conservation four years after the inscription. The findings indicate that since the UNESCO listing in 2008 , efforts in promoting heritage conservation in George Town have increased the awareness and appreciation of local residents especially amongst property owners. This could be due to the efforts (i.e. campaigns, incentives, conservation grants) initiated by the Government to create awareness of the importance of protecting and conserving heritage buildings. However, as this study revealed, some of the local residents are still not convinced with the economic returns/potentials of heritage properties as they refuse to pay more for a heritage property. Nonetheless, the older generation are found to be more willing to pay higher to own heritage properties given their sense of belonging and affection to the traditional and cultural elements of heritage buildings.

Besides that, the findings from this study clearly depicted that George Town's inscription into the UNESCO Heritage List has changed the local residents' preferences and awareness towards heritage conservation. More residents, especially property owners, prefer not to 
develop George Town into a modern city. A paradoxical situation has occurred whereby the younger generation tend to prefer modern city living and modern houses as opposed to the older generation who still prefer to remain in the historic city of George Town and dwell in heritage houses.

Though there are signs of increasing awareness and greater preferences towards heritage conservation by the local residents in this period after the UNESCO listing, nevertheless, more concerted efforts need to be undertaken by the various stakeholders to encourage more participation and foster inclusion within the local community, especially amongst the younger generation. Without doubt, the participation and awareness of the younger generation are of utmost importance and pivotal towards achieving sustainable urban conservation and development for George Town to remain as a historic city for posterity. As such, the management of the heritage site is not only just to preserve the old but also to encourage the young to embrace the traditional way of life as their own. In this respect, it is important that future research should focus on the perceptions of the young population and how they can be engaged in the conservation effort of the city of George Town.

\section{Acknowledgement}

The authors would like to express their thanks and appreciation to Universiti Sains Malaysia for funding this study under the USM Research University Grant Ref: 1001/PSosial.816188 and special thanks to our research assistant, Ms Nicole Chang Shu Fun for her dedicated help. The authors are grateful to all the respondents and parties involved for their time, assistance and cooperation.

\section{References}

ADENIRAN A. J., AKINLABI F. J. (2011), Perceptions on cultural significance and heritage conservation: A case study of Sussan Wenger's building, Osogbo, Nigeria, African Journal of History and Culture 3 (5), 73-88.

ADLER E. S., CLARK R. (1999), How It's Done: An Invitation to Social Research, Wadsworth Publishing Company, Belmont.

ADRIAANSE C. C. M. (2007), Measuring residential satisfaction: A residential environmental satisfaction scale (RESS), Journal of Housing and the Built Environment 22, 287 $-304$.

ASSARI A., MAHESH T. M., EMTEHANI M. R., ASSARI E. (2011), Comparative sustainability of bazaar in Iranian traditional cities: Case studies in Isfahan and Tabriz, International Journal on Technical and Physical Problems of Engineering (IJTPE) 3 (9), 18-24.

ASSARI A., MAHESH T. M., ASSARI E. (2012), Role of public participation in sustainability of historical city: Usage of TOPSIS method, Indian Journal of Science and Technology 5 (3).

AZMAN N., ABDUL HALIM S., KOMOO I. (2010), Public education in heritage conservation for Geopark community: A case for Langkawi global Geopark, Procedia Social \& Behavioral Sciences 7 (C), 504-511.

BOB U., SWART K. (2009), Resident Perceptions of the 2010 FIFA Soccer World Cup Stadia Development in Cape Town, Urban Forum 20, 47-59.

CARMONA M., HEATH T., OC T., TIESDELL S. (2003), Public places-urban spaces, The Dimensions of Urban Design, Architectural Press, Oxford.

CHETWYN D. J. (1999), Constructive design intervention: The city of Stoke-on-Trent design strategy for the built environment, Built Environment 25 (4), 356-370.

GRIMWADE G., CARTER B. (2000), Managing small heritage sites with interpretation and community involvement, International Journal of Heritage Studies 6 (1), 33-48.

HODGES A., WATSON S. (2000), Community-based heritage management: A case 
study and agenda for research, International Journal of Heritage Studies 6 (3), 231-243.

HOLLAND L. (2001), Whose Heritage?, Far Eastern Economic Review, Retrieved December 22, 2012, from http://pgoh13.free.fr/feer030501.html.

JIM C. Y., CHEN W. Y. (2006), Urban Green Spaces in Guangzhou, Environmental Management 38 (3), 338-349.

JUPP E., MUSGRAVE L., REEVE J., MASON M. (2002), People and places: Social inclusion policy for the built and historic environment, Department for Culture, Media and Sport, London.

KIM S. S., PETRICK J. F. (2005), Residents' perceptions on impacts of the FIFA 2002 World Cup: The case of Seoul as host city, Tourism Management 26 (1), 25-38.

LANTHIER E. (2002), Questionnaire, Retrieved October 3, 2012, from http://www.nvcc.edu/home/elanthier/methods/questionnaire.htm

LA FRENIERRE J. (2008), Mapping heritage: A participatory technique for identifying tangible and intangible cultural heritage, The International Journal of the Inclusive Museum 1 (1), 97-104

LEE L. M., LIM Y. M., NOR'AINI Y. (2009), Urban Conservation as a Real Estate Development Strategy for Revitalising the Inner City of George Town, Penang, NAPREC, Kuala Lumpur.

LIM B. C. (2005), My Penang. The Inside Guide to Where To Go and What To Eat, Lim Bee Chin, Malaysia.

LIM Y. M., LEE L. M., NOR'AINI Y., TAN S. F. (2008), Georgetown as a heritage city: The voices of residents, Paper presented at $14^{\text {th }}$ Pacific Rim Real Estate Society Conference, Kuala Lumpur, Malaysia.

MACDONALD S. (2012), Secondary cities are an untapped resource in Penang Penang Institute, Retrieved on 15 October 2014, from: http://penangmonthly.com/secondarycities-are-an-untapped-resource/

MCINNIS T. (2001), Pros and cons of establishing historic districts pondered in the Port, York Country Coast Star, Retrieved on December 20, 2012 from

http://www.seacoastonline.com/articles/20010905-NEWS-309059975?cid=sitesearch

MIRE S. (2007), Preserving knowledge, not objects: A Somali perspective for heritage management and archaeological research, African Archaeological Review 24, 49-71.

MOSER C. A., KALTON G. (1979), Survey methods in social investigation. $2^{\text {nd }}$ Edition, Heinemann Educational Books Ltd., London.

NABWIRE B., NYABENGE M. (2006), Community resource mapping in sustainable natural resource management: A case study of SW Uganda, The Electronic Journal of Information Systems in Developing Countries 25 (4), 1-8.

PEERAPUN W. (2012), Participatory planning in urban conservation and regeneration: A case study of Amphawa Community, Procedia Social \& Behavioral Sciences 36, 243-252.

POTTER R. B. (1985), Urbanisation and planning in the $3^{\text {rd }}$ world: Spatial perception and public participation, Croom Helm, London.

SHAW K., PORTER L. (eds.) (2009), Whose Urban Renaissance? An international comparison of urban regeneration strategies, 1-7, Routledge, Oxon. 405-411. SIRISRISAK T. (2009), Conservation of Bangkok old town, Habitat International 33,

SMITH L., MORGAN A., VAN DER MEER A. (2003), Community-driven research in cultural heritage management: The Waanyi women's history project, International Journal of Heritage Studies 9 (1), 65-80.

SPENNEMANN D. H. R. (1992), World War II remains on Central Pacific Islands: Perceptions of heritage versus priorities of preservation, Pac. Rev. 5 (3), 278-290.

SPENNEMANN D. H. R., HARRIS K. (1996), Cultural heritage of Culcaim Shire: Some considerations for strategic planning, Johnstone Centre of Parks, Recreation and Heritage Report 71, Charles Sturt University, Albury. 
SPENNEMANN D. H. R., LOCKWOOD M., HARRIS K. (2001), The eye of the professional vs. opinion of the community, Cult. Resour. Manage. 24 (2), 16-18.

SPENNEMANN D. H. R. (2003), Teacher and student perceptions of the cultural heritage of the CNMI: An empirical snap-shot, Micronesian J. Humanities and Social Sciences $2(1-2), 50-57$.

STATE GOVERNMENT OF PENANG (2011), Draft Special Area Plan. George Town. Historic Cities of the Straits of Malacca, State Government of Penang (ungazetted), Penang.

STEPHENSON J., BAUCHOP H., PETCHEY P. (2004), Bannockburn heritage landscape study, Department of Conservation, New Zealand, Retrieved on December 20, 2012, from http://csl.doc.govt.nz/Documents/science-and-technical/SfC244.pdf.

TAN S. F., FANG H. L. (2007), Preference and Awareness on Urban Heritage in George Town. A Survey Report, Research Project "Urban Conservation as a Real Estate Development Strategy for Revitalising the Inner City of George Town, Penang (Phase One)" for NAPREC, INSPEN, Unpublished Research Report.

THOMAS M. (2002), Moving landscapes: National parks and the Vietnamese experience; studies in the cultural construction of open space, National Parks and Wildlife Service, Sydney NSW.

TWYNAM G., JOHNSTON M. (2004), Changes in host community reactions to a special sporting event, Current Issues in Tourism 7(3), 242-261.

UNESCO (2008), Operational Guidelines for the Implementation of the World Heritage Convention, Retrieved on October 24, 2012, from http://whc.unesco.org/archive/opguide08en.pdf.

WONG J. (2012), Skyrocketing shophouses, The Star Online, Retrieved on December 11, 2012, from http://thestar.com.my/news/story.asp?file=/2012/3/21/metrobiz / 10824184 \&sec=metrobiz

WATES N. (2002), How people can shape their cities, towns and villages in any part of the world, The Community Planning Handbook, Earthscan Publications Ltd., London.

Initial submission: 09.07.2014

Revised submission: 07.12.2014

Final acceptance: 15.12 .2014

Correspondence: Department of Quantity Surveying, Universiti Sains Malaysia, 1800 Pulau Penang, Malaysia

Email: ymlim@usm.my 
